\title{
Flexion deformity of the finger caused by tophaceous gout of the flexor tendon
}

\author{
Jonathan James Hyett Bray, ${ }^{1}$ Sebastien Crosswell, ${ }^{2}$ Iqbal Hashmat ${ }^{2}$
}

'University of Bristol Academy, Bristol Royal Infirmary, Bristol, UK

${ }^{2}$ Department of Trauma and Orthopaedic, Gloucester Royal Hospital, Gloucester, UK

\section{Correspondence to Jonathan James Hyett Bray, Jonathan.Bray@doctors.org.uk}

Accepted 10 July 2017

\section{(1) CrossMark}

To cite: Bray JJH, Crosswell S, Hashmat I. BMJ Case Rep Published Online First: [please include Day Month Year]. doi:10.1136/ bcr-2017-220937

\section{DESCRIPTION}

A 53-year-old, right-handed man was referred to orthopaedic clinic with a 1-year history of progressive 'trigger-like' symptoms and eventual locking of the right ring and middle fingers. There was no history of trauma or joint problems. Medical history included stable chronic kidney disease and well-controlled hypertension. On examination of the right hand, there was limited passive mobility with complete flexion of the ring and middle fingers by $100^{\circ}$ at the proximal interphalangeal joint, and additionally the ring finger by $45^{\circ}$ at the distal interphalangeal joint. The left hand was unaffected. Furthermore, in the context of a raised serum uric acid concentration of $767 \mu \mathrm{mol} / \mathrm{L} 3$ years previously, two palpable, non-tender nodules were found on the left olecranon.

Surgical exploration of the right ring finger found multiple small, white speckled deposits infiltrating the flexor tendon from the first annular pulley (A1) to just beyond the A3 pulley (figure 1). The same deposits were found in the middle finger. In both fingers, the A1 pulley was released followed by washout and debridement, while leaving the tendon

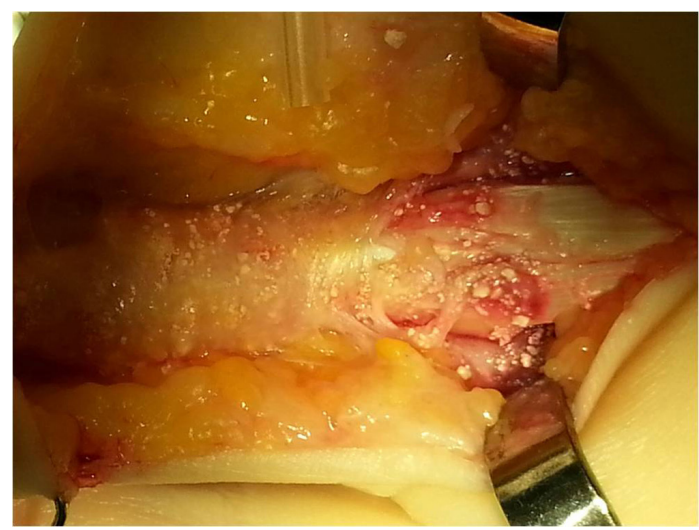

Figure 1 Intraoperative aspect of the right ring finger showing gouty deposits infiltrating the synovial sheaths of the flexor digitorum superficialis and profundus tendons. sheaths intact. A biopsy was taken which supported the clinical diagnosis of tophaceous gout. Postoperatively, function improved and rheumatological follow-up was arranged.

Gout only affects the hand in a minority of cases (16.9\%), and often only in the context of advanced disease. ${ }^{1}$ Moreover, specific involvement of the flexor tendons of the hand is uncommon. ${ }^{2}$ Tophi as the initial manifestation of gout is also unusual as tophi development is related to disease duration. ${ }^{3}$

\section{Learning points}

- Gout should be considered if presented with a fixed flexion deformity, especially in an individual with risk factors related to gout such as a man with hypertension-related diuretic therapy and renal insufficiency.

- Tophi uncommonly constitute the initial presentation of gout.

Contributors JJHB is responsible for writing the first manuscript, obtaining consent and reviewing the literature surrounding the case $\mathrm{SC}$ is responsible for obtaining the image. IH is the orthopaedic hand surgeon who performed the surgery, conceptualised the case report and thoroughly reviewed the introductory and background literature. All authors edited and reviewed the manuscript and have approved the final version.

Competing interests None declared.

Patient consent Obtained.

Provenance and peer review Not commissioned; externally peer-reviewed.

(c) BMJ Publishing Group Ltd (unless otherwise stated in the text of the article) 2017. All rights reserved. No commercial use is permitted unless otherwise expressly granted.

\section{REFERENCES}

1 Mallinson PI, Reagan AC, Coupal T, et al. The distribution of urate deposition within the extremities in gout: a review of 148 dualenergy CT cases. Skeletal Radiol 2014;43:277-81.

2 Meyer zu Reckendorf G, Lupascu D. Flexor tendons involvement in gout. A case report and review of literature. Chir Main 2010:29:199-202

3 Wernick R, Winkler C, Campbell S. Tophi as the initial manifestation of gout. Report of six cases and review of the literature. Arch Intern Med 1992;152:873-6. 
Copyright 2017 BMJ Publishing Group. All rights reserved. For permission to reuse any of this content visit http://group.bmj.com/group/rights-licensing/permissions.

BMJ Case Report Fellows may re-use this article for personal use and teaching without any further permission.

Become a Fellow of BMJ Case Reports today and you can:

- Submit as many cases as you like

- Enjoy fast sympathetic peer review and rapid publication of accepted articles

Access all the published articles

- Re-use any of the published material for personal use and teaching without further permission

For information on Institutional Fellowships contact consortiasales@bmjgroup.com

Visit casereports.bmj.com for more articles like this and to become a Fellow 